\title{
Television vampire fandom and religion
}

\section{Introduction}

Popular culture and fandom provide a setting where people can reflect on the questions of life. Jennifer Porter, who has studied the religious aspects of Star Trek fandom, says that Star Trek defines for many of its fans what it means to be human. It also discusses the way things are, and the way they should, or could, be in our reality (Porter 2009: 278). In this article I will show that television shows Buffy the Vampire Slayer (1997-2003), True Blood (2008-) and the Vampire Diaries (2009-) have made the same kind of impact on their fans.

The notion that institutional forms of religion have decreased in Western culture is broadly recognized, even though the extent of this development is being discussed. Religion has become a more private matter, based on personal choices, and it is being practised outside of religious institutions (see e.g. Bruce 1996, Kääriäinen et al. 2003, Possamai 2005). The need to understand reality, to get a confirmation of values, find hope for the future and a community in which people can be themselves has not vanished, even though the interest in religious institutions is decreasing in Western societies.

People search for the religious building blocks of their worldviews from different sources, and the media is one of them. Religion and popular culture scholar Conrad Ostwalt argues that people go to movies and read books because these forms of popular culture function like traditional religions. Popular culture offers ways to understand reality and life. People increasingly seek in popular culture the meaning, identity and community that was once found in religion (Ostwalt 1995: 158; Ostwalt 2003). People build their worldviews and religiosity by taking elements from different cultural products such as films, literature, music and games (Pesonen et al. 2011: 14).

In this article I will argue that the fandom of the television series Buffy the Vampire Slayer, True Blood and the Vampire Diaries have many aspects that connect them to religion. My aim is not to say that fandom is perceived by the fans as a religion, or that it is felt to be a religious choice to be a fan. Rather I agree with the notion presented by Sean McCloud that '[b]oth religion and popular culture help people create and infuse their lives with meaning, iden- 
tity, community, memory, tradition, and power through the use of various cultural items' (McCloud 2010: 335). The term religion in my study refers to the ways in which people make sense of their lives culturally, are a part of a community, re-enforce and share values, share experiences, and find hope and solace in life crises. In this article I analyse aspects of vampire television fandom with reference to Ninian Smart's understanding of religious dimensions (Smart 1998). I will also consider the connection between fandom and lived religion, mainly through the work of Meredith McGuire (2008). In my analyses I will use information and material I have gathered from internet fan sites, forums and blogs of Buffy, True Blood and the Vampire Diaries.

\section{Buffy the Vampire Slayer, True Blood and the Vampire Diaries}

Vampires are figures that come and go in popular culture and they always evolve to meet the needs of a specific time (see e.g. Hakola 2011). The current fascination and visibility of vampires in popular culture is largely due to the Twilight phenomenon, based on the books of Stephanie Meyer. This phenomenon has made it possible for True Blood and the Vampire Diaries to be aired, even though they portray very different kinds of vampire stories. Buffy the Vampire Slayer, on the other hand originated before the current vampire frenzy, and it has influenced all of the present television and film representations of vampires. Buffy, True Blood and the Vampire Diaries are all shows that have formed their own fan bases. Also many of the fans of one show are at least familiar with the other two shows, or even fans of them too. The vampire genre usually connects fans together, but being part of the fandom of one vampire lore can also make it hard to accept different kinds of vampire stories.

Buffy the Vampire Slayer was a very remarkable show because it influenced the entire teenage, fantasy, horror, and action genre. Buffy was originally made as a movie in 1992, but it was not a success. However the screenwriter Joss Whedon, whose original idea the Buffy character was, got another chance to tell the story of Buffy on television. Buffy portrays the coming-ofage story of a teenage girl, but with an added twist of fantasy and horror. The girl has superhuman strength and mental abilities because her task in life is to kill vampires and demons. Fortunately she does not have to do it alone; she has help from a watcher, who trains her, as well as from her best friends a witch, a werewolf, and a regular guy with lots of courage. She also gets help from her vampire boyfriend, who is a good guy because he has regained his human soul. The basic story tells of a girl who can save the world and who has 
friends to support her in this effort. The heroism is based on the community of friends. The evil of the world is not something outside of people, but stems from weakness and fear which makes people hurt each other. In Buffy the world is a place where bad and sad things happen to everyone, but the fight against the evils which are in ourselves or in the actions of others, is the only right thing to do.

Buffy the Vampire Slayer was on television for seven seasons and it formed a large international fan base. The makers of the show have often talked about the way the fans made it possible for the show to be picked up for second season. At the end of the 1990 os internet communities were beginning to form and fans of Buffy found each other online. They also spread the word about the show to other potential audiences. In media studies the online Buffy fandom has been seen as one of the first to influence television production. In addition to helping the show to be picked up for continuing seasons, the fans' opinions sometimes influenced the way the storyline and the characters were written. The internet fan sites of Buffy were regularly read by the producers and writers of the show. The fandom of Buffy has remained strong, even though the show has been off the air for almost ten years. New fans have found the show on DVD or the internet, and the fan communities, as well as new productions from Joss Whedon, keep the old fans active.

True Blood is based on the Sookie Stackhouse book series (2000-) written by Charlaine Harris. The television show, produced by $\mathrm{HBO}$, has changed a lot of the characters, stories and even themes of the books. Like Buffy, True Blood also has a young woman as a heroine, and she also has superhuman powers. Sookie Stackhouse is a telepath in the small town of Bon Temps and the story begins when she meets and falls in love with vampire Bill. In True Blood the vampires have 'gotten out of the coffin' and revealed their existence to humans, because of synthetic blood (Tru Blood) that can fulfil their need for human blood. The world of True Blood is filled with supernatural features and beings such as vampires, werewolves, shapeshifters, fairies and witches. In all of these groups there are good and bad individuals, just as there are among humans.

As a heroine Sookie walks in the footsteps of Buffy: she stands up to all the other supernatural beings that threaten her. True Blood is clearly targeted to a more mature audience than the teenager-oriented shows Buffy and the Vampire Diaries. The world is darker, the violence and sex are shown very explicitly, and current social problems are addressed more noticeably. But the themes addressed in True Blood are similar to Buffy and the Vampire Diaries. One main theme in all of these shows is how to be good; who can be good 
and how to make amends for bad things. The monsters in these shows are also often the humans, while the creatures who look like monsters are seeking ways to be good.

The Vampire Diaries is based on a book series, the Vampire Diaries (1991-) written by L. J. Smith. The Vampire Diaries is basically a teen show, but it has all the same themes of right and wrong, good and evil, life and death that the other shows have. The heroine is Elena, who is also a supernatural being: a doppelganger. Vampire brothers Stefan and Damon both love Elena and try to redeem themselves in order to be good vampires. As in Buffy the evil vampires are beaten by the community of Elena's friends, which includes a witch, a vampire, a werewolf and Elena's brother who is a regular guy with a lot of courage.

\section{Fandom and popular culture}

Fandom has become a more respected way to show one's interest in something. People speak more openly about the things that interest them, and they also more often call themselves fans. The term fan is difficult to define. As the media scholar Kaarina Nikunen has pointed out, the term fan is used to refer to many different forms and degrees of involvement. People can also be fans of many different things. The term was originally related to sport audiences and sport fandom is still one of the most visible forms of fandom. Usually in media studies fandom is seen as a strong and passionate admiration that is connected to a popular cultural phenomenon. Nikunen also points out that fandom can be seen as being extreme and commonplace at the same time (Nikunen 2005: 18).

An extreme aspect of fandom is the way fans are viewed as fanatical about and overly enthusiastically involved with the object of their interest. The media scholar Henry Jenkins fought this kind of understanding of fans in his groundbreaking fan study Textual Poachers (1992). At that time the term fan was usually connected to people whose interests in popular culture seemed strange and who were seen as being dangerously out of touch with reality. Jenkins claimed that the fans' involvement in something that is not generally considered to be art or higher culture threatens the cultural hierarchies of taste, and that is why fans have been labelled as something not normal. But 'good taste and aesthetic merit are not natural or universal' (Jenkins 1992: $12-13,16)$. They are culturally constructed by those who have more influence and cultural power (see e.g. Herkman 2001). Because fans are dedicated to 
something that is generally seen as mere mass entertainment, their involvement seems odd and misplaced. Also the commercial interests of popular culture are often emphasised and fans are seen merely as passive consumers. Jenkins' work helped to change the academic understanding of fans, when he showed in his study that fans can be active producers and manipulators of meanings (Jenkins 1992: 23). The negative stereotype of fandom however still persists in the everyday usage of the word.

The commonplace aspect of fandom is connected to how the ordinary and routine things around us construct our conceptions and values without us even noticing it (Nikunen 2005: 19). In media studies fandom is seen as meaning-making. Fans use the objects of their fandom, as well as the fandom itself, as a part of the process through which they construct their identities. The audience's socio-cultural background and their own life experiences are the basis from which the television shows' stories, worldviews, and values are reflected upon. Through this process people give meaning to what they see. Many scholars believe that popular culture can provide meaningful experiences. The enjoyment and positive feelings gained from it can be important resources to help get though everyday life. In popular culture and fandom there is also usually a strong community aspect. Popular culture can provide knowledge and models to follow that people can use in their daily lives. This has been seen as an example of popular culture empowering people (Herkman 2007: 24).

\section{Vampire fans and the internet}

Internet fan forums are the places where fans meet and discuss the shows. There are a lot of different sites that are dedicated to the shows. There are international and national fan sites that mainly interconnect information about the shows. Each show has its own official site, but all the rest are created and maintained by the fans. Fan sites may include discussion forums, but mainly these are separate. There are discussion forums about specific shows. Fans also meet to discuss the shows on sites that give information about television shows and films in general, like Internet Movie Database (IMDb) and Television Without Pity (TWoP). Facebook and Twitter are used extensively by fans as well. The shows have their own Facebook pages, and fans form groups and keep in touch by Facebook. On Twitter fans follow the actors and chat amongst themselves. Fans also write blogs. 
Plot twists and the characters are the most discussed topics on these sites. At first glance the forums appear to be a place where people talk to their friends after watching something entertaining. This is a part of it, but the relationships of the shows and the fan community are more complex. To many fans the shows have a deeper meaning than just entertainment. Fans can also have close relationships with people around the world on the basis of their common fandom.

\section{Fandom and the practical and ritual dimensions}

Ninian Smart has formed a list of seven religious dimensions so that: 'we can give a balanced description of the movements of which have animated the human spirit and taken a place in the shaping of society, without neglecting either ideas or practices' (Smart 1998: 21). To understand television vampire fandom better it is useful to analyse it by means of this list of dimensions, as well as to look at the connections between fandom and lived religion.

According to Smart every religious tradition involves practices such as worship, preaching, prayers and meditation (Smart 1998: 13). In the fandom of Buffy, True Blood and the Vampire Diaries the practical and ritual dimensions take the form of watching the shows, going online to discuss them and meeting other fans. Watching the shows provides an everyday ritual. The fans adapt their schedules in order to be able to see the shows. It can also be an escape from the routines and demands of everyday life:

True Blood is the one thing I can count on right now. I'm going to school, pre-med, and working almost full time and when Sunday night comes around, my world stops so I can be taken away into the fictional town of Bon Temps, or wherever the show is in the night's episode. It gives me an hour to just dissociate from myself and enjoy the show. No show or movie has ever done that. It's almost existential. I love the show and all the fans around the world that I talk to on Twitter and IMDb. ... It's an amazing show, with an amazing fan base, and while I don't have many friends that watch the show, I feel a part of a fantastic - and LARGE - group of people! (The Vault 2011a).

This fan uses True Blood as an escape from life's pressures. For an hour she can just be. The escape has brought another positive aspect into her life; the fan community. The show that has a meaningful role in her life and routines has 
also given her a new social group to belong to. She has become a part of the fan community online.

The religious studies scholar Sheila Briggs has pointed out that cult television shows, such as Xena the Warrior Princess, engage their fans in the same activities that provide the texture of everyday life in religious communities. These are, for example, sharing common meals, acting for social justice, finding comfort in illness, and receiving and giving solace (Briggs 2009: 174-5). The fans of vampire shows share common meals at meetings and conventions, usually organized by the fans themselves. The fans act for social justice by doing voluntary work, activism for equality, and collecting funds for charity. Some have even changed their occupation to become social workers. Fans have found hope, support and strength to carry on, from both the shows and the fan community.

These practices are not exclusively part of the realm of religious behaviour, but they are part of the notion of lived religion as 'what matters' to people (Orsi 2010: lxi). The media and religion scholar Diane Winston argues that applying the concept of lived religion to entertainment media would make it possible to reconsider seemingly temporary narratives as being part of the cultural material that helps us to make sense of our lives, our relationships, and our search for meaning. According to Winston, a lived religion can be detected in the ways the viewers watch television and integrate it into their daily experiences and meaning-making (Winston 2009a: 5 and 2009b: 428). Popular culture can be seen to be producing and reflecting a form of lived religion, the everyday religiosity that is not necessarily connected to religions institutions (Pesonen et al. 2011: 14).

\section{Experiential and emotional dimensions}

Smart argues that emotions and experiences are significant in the formation and development of religious traditions and play an important part in all the religious dimensions. Rituals, doctrines and myths lose their meaning as '[r]itual without feeling is cold, doctrines without awe or compassion are dry, myths which do not move hearers are feeble' (Smart 1998: 14).

Here is an example of the emotional connection and experience fans can get from the shows:

I had been attacked and he was part of the team of crisis workers who helped me get through my experience. ... I didn't believe I would ever 
be able to be loved or accepted, that I was damaged. X and I eventually started talking about Buffy and how it had motivated him to become a crisis worker, to fight the good fight, and to understand his life in a whole different level. ... I saw Buffy finally and it blew me away - Buffy tasked to fight demons, never having a choice and yet struggling to make it right, wondering if being a Slayer will prevent her from ever having a normal life then being loved by Angel. I knew that feeling; it was like there was hope in me for the first time in months.... It's given me the ability to love, laugh and feel again, to understand that life can be terrible and hard, scary and messy and complicated, but worth walking through (Buffy essays blog 2011).

The fandom of the crisis worker created the fandom of the writer, as he encouraged her to watch the show. The writer of this message was struggling with a horrible experience and found in Buffy something she could relate to. The writer saw the fight in her own life as something similar to Buffy's struggles. The fictional character overcoming obstacles in her life gave her hope. The experience of watching the show, as well as talking about it with the crisis worker, had the effect of bringing normal human experiences and feelings into the life of the writer. She also formed an understanding of life through the show, which was in accordance with her history as a victim of violence. In Buffy it is emphasized that in life there are hardships and suffering, but it is worth the fight.

The other theme of the text, the hope gained from Buffy, is also a feature of Star Trek fandom as well. Porter has noticed that:

Star Trek fans speak of Star Trek as something that gives them hope for the future, that provides solace in times of grief or fear, that motivates them to keep going when life seems darkest, that sparks in them the experience and conviction that life makes sense (Porter 2009: 278).

Even though the vampire shows don't seem to have much in common with Star Trek, they both influence their fans the same way.

Many fans have written online that 'the show saved my life' of that 'without the show I'd be dead by now'. This may seem to be an overestimation of the power of these television programmes. But the reality is that many fans have had to deal with mental or physical abuse at school, depression, and other serious adversities in their youth or early adulthood. In these situations the television shows and the fan communities have provided a way to survive. The next fan text is about this: 
I feel like I'm a part of something exciting. I have something to look forward to. My life was falling apart until I first saw the Vampire Diaries. The show saved my life. I'm so in love with it and I'm really thankful to everyone on the show. Without you guys I'd be dead by now (Vampire Diaries

Forums 2011).

The text is very short, but it reveals the reality of many fans' lives. Life is difficult, a struggle, and you need something to hold on to, something to look forward to. The fan has used the Vampire Diaries as a lifeboat. Anticipation about the show's next episode has given him enough hope to get through the week, to survive life. This is also a very important and often visible aspect of the fan writings. The shows provide a beacon of light that the fans can follow, and gradually get out of the darkness of their current life situations.

\section{The narrative or mythic dimension}

The narrative or mythic dimension refers to the sacred stories of religion(s). They can be about, for example, the beginning of the world, and the end of the world, about heroes and heroines, or about evil (Smart 1998: 15). The stories of the vampire shows are the basis of fandom. Diane Winston sees televisionwatching as a link in the chain of sacred storytelling. Winston connects these television stories to the Christian traditions of hearing the scriptures, or reading stained glass windows (Winston 2009a: 2).

An interesting example of the connection between popular culture and mythology is from Terhi Utrianen's study of the suicide notes of Finnish women. Their contents showed that women used quotes from well-known poems and lyrics from Finnish popular music in places where they wanted to say something that was hard to put down in words, but was still something very important. The quotes appeal to shared understandings of values; what matters in life, and the relationship between life and death. Utrianen sees the use of these texts as a way of referring to current Finnish myths which have been woven together from different cultural elements, including popular culture (Utriainen 1997: 109-10).

Diane Winston sees that social and cultural concerns and metaphysical questions are presented in the stories on television. These stories then explore and shape notions of identity and destiny (Winston 2009a: 2). The existential questions that have long been responded to in religious myths are now part of the storytelling in television shows. The television stories also fulfil 
the functions of myths by forming values and offering models of behaviour. One difference is that myths were previously said to uphold the unity of the community (Sjöblom 1997: 45). Television myths form the community by bringing together people who share the values and ideals which are being presented in the shows.

Death is one of the most manifest features of these vampire television myths. The media scholar Outi Hakola argues that the living dead characters of Hollywood cinema bring out the problematic presence of death in our lives and in our culture. On the other hand, these films reveal how important it is for the viewers to confront and deal with death, and the questions revolving around it. Hakola's research shows how the treatment of death in the movies with the portrayal living dead characters gives the audience an opportunity to contemplate their own mortality (Hakola 2011: 236, 245).

\section{The doctrinal and philosophical dimension}

Doctrine is formed out of the structured and considered beliefs of the tradition, which are shaped from its narratives (Smart 1998: 17). Television shows or fandoms do not have their own doctrines which the fans would see as something they believe in, or that they have to follow. For example, most fans do not believe that vampires walk among us, or that the magic represented in the shows is real. The doctrinal and philosophical questions arise from Christian traditions, folk beliefs and other values which are current in Western culture. People do not watch these shows in a cultural vacuum. They are interpreting them through the prism of their own culture, worldview, values and life histories. The vampire shows give the viewers stories that are grounded on familiar mythologies and they the share common values and socio-cultural reality of the audience.

Christopher Partridge, a scholar of contemporary religion, argues that the supernatural seen in television can influence people's beliefs. Popular culture can reshape understandings of what is possible in the world and what is not. As one example Partridge has taken the positive portrayal of Wiccans, or witches, in Buffy. Partridge sees that this has influenced viewers, especially young women, motivating some to take an interest in the Wiccan religion and becoming members themselves (Partridge 2004: 130-3). Religious studies scholar Jaakko Närvä who has studied belief in UFOs also points out that film presentations of aliens have a close correlation to the ways people describe their UFO experiences. The images are very similar, and fresh ways in which 
aliens are presented in the films will quickly be seen in the people's UFO stories (Närvä 2011). The kind of belief-formation Partridge and Närvä refer to is not evident in my material, but nevertheless the vampire shows influence the way fans perceive their lives and reality.

Aspects of the Christian tradition can be detected in these vampire shows. This is not a surprise, because they are made for an audience in the United States. The Christian tradition is woven into Western culture. In the shows the concepts of the soul, life after death, demons, heaven and hell are all apparent. The questions of life are discussed through concepts associated with the Christian tradition. For example in Buffy a soul is what distinguishes humans from demons, and when Buffy dies she goes to heaven. It is easy for people to connect to the stories and ideas that are familiar to them. Vampire shows use this familiarity, but adjust the tradition to make it interesting for the audiences of today. In connection with current Western culture, the Christian tradition and its institutions are also criticized in vampire shows, especially concerning the rights of women and homosexuals.

Fans do not usually perceive their fandom to be a religious activity. But there are also exceptions; fans who do see their fandom as being a part of their religious commitment. One fan talked about the way she had been mentally abused at school and she wrote that:

I myself am a Christian. And call me creepy, but I like to see it as God sort of gave me Buffy to get me through the roughest years of my life (What Buffy means to you 2011).

The fan connected her religious beliefs with the hope and solace she had received from Buffy. It is interesting that despite her religious commitment she did not find her consolation in a church, but in television. This comes very close to the idea of a lived religion. One of the scholars involved in forming the concept of lived religions, Meredith McGuire, argues that the commitments to religious groups or belief systems do not necessarily determine the everyday practice and meaning-making of individuals. Even though people belong to religious groups or institutions, their most meaningful religious practices and beliefs can be, for example a civil activity, or gardening (McGuire 2008: 6-8). McGuire says that ' $\mathrm{t}$ ] he religious practices and stories with which people make sense of their lives are always changing, adapting and growing' (12). 


\section{The ethical and legal dimension}

The values of a tradition are affected by narratives and doctrines. A law that has been incorporated by a tradition can be called the ethical dimension of that religion (Smart 1998: 18). The reflection and action upon the values presented in the vampire narratives is clear in many fan texts. This is about True Blood:

There are a lot of shows out there that make you think about life and death, but this show brings to the table so much more. It shows the taboos and lines that people don't want to cross in television or even in life. This show really makes me think about how I feel about my life and other lives and even underlining feelings that I have on certain subjects. I love how this show brings out the raw feeling of what life and death is all about (The Vault 2011b).

This message shows how the fan is reflecting on his values and his understanding of reality through the show. True Blood, like the other vampire shows, deals with questions of good and evil, life, death, and the meaning of it all. The shows also connect these questions to our current reality, and the values of our contemporary culture are reflected upon. These include questions about the roles of men and women, sexuality, homosexuality, cultural fears, how we should face people who are different from 'us' and how we should treat people from cultural minorities. I think these are the issues that have made this fan reflect upon his values and understanding of life.

In the fan's text which was presented earlier, a crisis worker introduced Buffy to an attacked woman. The crisis worker had changed the course of his own life, inspired by the heroic model of Buffy and the worldview given in the show. The worldview in Buffy is that bad things do happen to good people, the evils of life are usually caused by humans, and that even though the world will always have evil in it, the fight against it is valuable and really the only thing to do. These aspects of the show are not the only reason why the crisis worker started to 'fight the good fight', but they resonated with his own values and understanding.

The theme of models to follow is also an aspect of other fandoms. Jennifer Porter writes that the ideology of Star Trek has influenced fans to do volunteer work at food banks and soup kitchens, to donate for charity and to support the United Nations (Porter 2009: 278). Fans are fighting for the ideals of the show in real life, trying to make a difference. This is seen in both the fans of Star Trek and Buffy the Vampire Slayer, as the fan message above implied. 


\section{The social and institutional dimension}

Religious movements are embodied in groups of people. The social and institutional dimension refers to the way a faith works among people (Smart 1998: 19-20). The myths that are represented in the vampire television shows form new communities. People who have found something special in these shows find others like themselves on the internet. It is interesting that the fans have same kinds of experiences of the shows. The meaning of the community can be seen in the fan texts presented earlier. The importance of the fan community is clear also in that fans have written on the internet about their experiences and others have continued the conversation. Community is an essential part of fandom and the relationships within the community can become very important to fans.

Even though people can choose what stories they find meaningful, after finding them they form a community. Whilst in earlier periods of human history the community would offer shared stories, the myths, now in our world of new media people find stories that are meaningful to them and then build the community. In my source material most of the fans are active in fan communities and write about the meanings of the relationships with other fans, and the thrill of being a part of that community. But there are many fans who are not actively involved in fan communities. This does not however mean that they are not a part of the community that has been formed. Shared interests connect people and community can be experienced at fan events, where people do not know each other, but are still part of the same group.

Also the fan community is a place in which people can openly be themselves. Even though fandom is more broadly accepted than before, adult fans especially say that other people do not usually understand their involvement in fictional characters and stories. The fan community gives an opportunity to discuss meaningful stories, emotions and characters with others, who also find all this important in their lives.

\section{The material dimension}

The material dimension of religion is connected to buildings and works of art, but also to natural features, such as the mountains or rivers that people have connected with sacred elements (Smart 1998: 21). The material dimension in fandom is the shows themselves, the DVDs, the merchandise connected to the shows, and the fan conventions. The merchandise especially - including 
posters, figurines, bags and jewelry - maintains the presence and visibility of the fandom. Fan meetings and conventions are decorated by the images and themes of the shows and people also dress up. These material aspects help to create feelings of community and shared experience.

Television vampire fandom has many links to the dimensions of religion. Smart has also noticed that these dimensions can also be found in various philosophical or social phenomena, such as communism. Smart argues that it is not appropriate to call these phenomena religions, because the participants themselves understand them to be antireligious. Smart, on the other hand, continues to say that the secular worldviews, systems of ideas and practices, are competitors and play in the same league, whether they are religious or not. 'They all help to express the various ways in which human beings conceive of themselves and act in the world' (Smart 1998: 26).

\section{Conclusion}

Popular culture is a significant aspect of current reality. It influences us without us even noticing, and it is easily accessible. The fan writings of Buffy the Vampire Slayer, True Blood and the Vampire Diaries show that these popular texts, and the communities they have formed, have greatly affected the lives of fans. People have found on their TV-screens stories they can get strength and hope from. The vampire shows deal with the supernatural - vampires, werewolves, and witches - and place them in our contemporary world as if they are a natural part of it. Television vampire stories revolve around topics of death, good and evil, and humanity. These stories have created massive fan communities and even life-changing fan experiences. The reflections upon existential questions, and the way the shows have empowered fans, make this phenomenon important to study in the context of today's religions reality.

I argue that according to Ninian Smart's religious dimensions fandom can be seen as a religious phenomenon. Smart found that secular worldviews such as Marxism - may also have many characteristics that link them with these religious dimensions. This shows that the aspects are not only a part of phenomena that are perceived by their followers to be religious. I argue that it is meaningful to connect fandom to the realm of religion, because it fulfils the same needs. Fandom can be seen as a part of our current society's religious reality, where people search for meaning, as well as for reinforcements of their values and beliefs, from many different sources. I argue that people need elements upon which they can form and shape their worldviews and identities. In some form or another, people search for answers to the ques- 
tions of life, death, the nature of reality, good and evil, right and wrong, the meaning of our existence. And popular culture can provide those answers for some people.

The connection to lived religion also confirms that fandom is closely related to the phenomenon which is understood as religion. Vampire television fandom has many characteristics which come close to the everyday practices of lived religion, such as a daily practice of watching television or going online, community activities, and seeking meaning and consolation. Fandom fulfils the function of understanding one's reality by confirming cultural values and beliefs. Fandom also offers individuals the opportunity to be a part of a community by bringing together people who share an interest in the same stories and myths. And, finally, fandom provides a source of hope and solace. Also the beliefs and values of our current reality are represented in these shows, and they resonate to the audience's worldviews and identities.

\section{References}

\section{Internet sources}

\section{Buffy essays blog}

2011 Buffy essays blog. <http://buffyessays.blogspot.fi/2007/04/welcome.html> (accessed 25.5.2011).

\section{Vampire Diaries Forums}

2011 Vampire Diaries Forums. <http://forums.vampire-diaries.net/viewforum. php? $\mathrm{f}=8 \& \mathrm{t}=6164 \& \operatorname{start}=10>($ accessed $23 \cdot 5 \cdot 2011)$.

\section{The Vault}

2011a The Vault, message 38.<www.trueblood-online.com/tell-us-how-true-bloodchanged-your-life $>$ (accessed 20.5.2011).

2011 b The Vault, message 12.<www.trueblood-online.com/tell-us-how-true-bloodchanged-your-life $>$ (accessed 20.5.2011).

\section{What Buffy means to you}

2011 Facebook: What Buffy means to you. <http://www.facebook.com/topic. php?uid $=2204489777 \&$ topic $=2419>($ accessed 19.5 .2011$)$.

\section{Bibliography}

Brigs, Sheila

2009 'Elect Xena God': religion remixed in a (post-) television culture. In Diane Winston (ed.), Small Screen, Big Picture: Television and Lived Religion; pp. 173-99. Baylor: Baylor University Press.

\section{Bruce, Steve}

1996 Religion in the Modern World: from Cathedrals to Cults. New York: Oxford University Press. 


\section{Hakola, Outi}

2011 Muumiot ja pakanallisen kuoleman uhka. In Heikki Pesonen, Elina Lehtinen, Nelli Myllärniemi and Minja Blom (eds), Elokuva uskonnon peilinä. Uskontotieteellisiä tarkennuksia länsimaiseen populaarielokuvaan; pp. 23048. Helsinki: Helsingin yliopisto.

\section{Herkman, Juha}

2001 Audiovisuaalinen mediakulttuuri. Tampere: Vastapaino.

2007 Kriittinen mediakasvatus. Tampere: Vastapaino.

\section{Jenkins, Henry}

1992 Textual Poachers: Television Fans and Participatory Culture. New York: Routledge.

\section{Kääriäinen, Kimmo, Kati Niemelä and Kimmo Ketola}

2003 Moderni kirkkokansa. Suomalaisten uskonnollisuus uudella vuosituhannella. Tampere: Kirkon tutkimuskeskus.

\section{McCloud, Sean}

2010 Popular culture. In Daniel Stout (ed.), The Routledge Encyclopedia of Religion and Media; pp. 333-6. New York: Routledge.

\section{McGuire, Meredith}

2008 Lived Religion: Faith and Practice in Everyday Life. Oxford: Oxford University Press.

\section{Närvä, Jaakko}

2011 Tarusta totta. Ufoelokuvat ufouskomusten lähteinä. In Heikki Pesonen, Elina Lehtinen, Nelli Myllärniemi and Minja Blom (eds), Elokuva uskonnon peilinä. Uskontotieteellisiä tarkennuksia länsimaiseen populaarielokuvaan; pp. 154-73. Helsinki: Helsingin yliopisto.

\section{Nikunen, Kaarina}

2005 Faniuden aika. Kolme tapausta TV-ohjelmien faniudesta vuosituhannen taitteen Suomessa. Tampere: Tampere University Press.

\section{Orsi, Robert}

2010 (1985) The Madonna of the 115th Street: Faith and Community in Italian Harlem, 1880-1950. Third edition. New Haven: Yale University Press.

\section{Ostwalt, Conrad}

1995 Conclusion: religion, film, and cultural analysis. In Joel W. Martin and Conrad Ostwalt (eds), Screening the Sacred: Religion, Myth, and Ideology in Popular American Film; pp. 152-6o. Boulder: Westview Press.

2003 Secular Steeples: Popular Culture and Religious Imagination. Harrisburg: Trinity Press.

\section{Partridge, Christopher}

2004 The Re-enchantment of the West, vol. 1. London: T\&T Clark International.

Pesonen, Heikki, Elina Lehtinen and Nelli Myllärniemi

2011 Kuinka tutkia uskontoa elokuvassa? Lähtökohtia, periaatteita ja näkökulmia. In Heikki Pesonen, Elina Lehtinen, Nelli Myllärniemi and Minja Blom (eds), 
Elokuva uskonnon peilinä. Uskontotieteellisiä tarkennuksia länsimaiseen populaarielokuvaan; pp. 10-45. Helsinki: Helsingin yliopisto.

\section{Porter, Jennifer}

2009 Implicit religion in popular culture: the religious dimensions of fan communities. Implicit Religion 12(3): 271-80.

\section{Possamai, Adam}

2005 Religion and Popular Culture: a Hyper-Real Testament. Brussels: P.I.E.-Peter Lang.

\section{Sjöblom, Tom}

1997 Myyttien synty, rakenne ja mieli. Strukturalistisen myyttitutkimuksen kritiikkiä. In Tom Sjöblom (ed.), Tutkija, tekstit ja uskonto; pp. 44-59. Helsinki: Helsingin yliopisto.

\section{Smart, Ninian}

1998 The World's Religions. Second edition. Cambridge: Cambridge University Press.

\section{Utriainen, Terhi}

1997 Tekstien risteykset, tekstien kerrokset. Intertekstuaalisuudesta ja uskonnontutkimuksesta. In Tom Sjöblom (ed.), Tutkija, tekstit ja uskonto; pp. 102-17. Helsinki: Helsingin yliopisto.

\section{Winston, Diane}

2009a Introduction. In Diane Winston (ed.), Small Screen, Big Picture: Television and Lived Religion; pp. 1-14. Baylor: Baylor University Press.

2009b Epilogue. In Diane Winston (ed.), Small Screen, Big Picture: Television and Lived Religion; pp. 227-31. Baylor: Baylor University Press. 